\title{
Petrographic Investigation of Target Rock Transformation under High Shock Pressures from the Colônia Impact Crater, Brazil
}

\author{
Victor F. Velázquez ${ }^{1}$, Rodrigo F. Lucena ${ }^{1}$, Jose M. Azevedo Sobrinho ${ }^{2}$, Alethéa E. Martins Sallun ${ }^{2} \&$ William \\ Sallun Filho ${ }^{2}$ \\ ${ }^{1}$ School of Arts, Sciences and Humanities, University of São Paulo, São Paulo, Brazil \\ ${ }^{2}$ Geological Institute, Environmental Secretariat of São Paulo State, São Paulo, Brazil \\ Correspondence: Victor F. Velázquez, School of Arts, Sciences and Humanities, University of São Paulo, São \\ Paulo, Brazil, Tel: 55-11-3091-8150. E-mail: vvf@usp.br
}

Received: July 15, 2017

doi:10.5539/esr.v7n1p13
Accepted: July 29, 2017

Online Published: September 24, 2017

URL: https://doi.org/10.5539/esr.v7n1p13

\begin{abstract}
The Colônia impact crater, developed on crystalline basement rocks, offers an excellent example of one of the most unique features of the impact process: the effects of shock waves on textural and mineralogical changes of the target rock. The impact melt-bearing impactites were derived essentially from the igneous and metamorphic rocks, including granite, mica schist, granitic gneiss, and quartzite. Investigations using optical microscopy indicate that the effect of shock waves on those lithologies caused a wide variety of deformation features and generation of new materials. The most common features include fluidal textures, unusual rearrangement patterns between grains, recrystallization, decomposition and precipitation of new phases, agglutination of glassy and crystalline spherules, and the mobilized melt formed different types of impact melt particles. These transformations cover processes that may involve a new grain growing at the expense of parental grains of the same species, or crystallization of different mineral types from component-providing grains until a complete textural and compositional change of the target rocks occurs. Small-scale structures in deformed rocks are particularly interesting for exploring elastic-plastic deformation, phase transformations, and generation of impact melt products.
\end{abstract}

Keywords: colônia impact crater, impactites, texture transformation, melt product, impact spherules

\section{Introduction}

The formation of hypervelocity impact craters on the Earth's surface is a geologic process that occurs in a highly dynamic physical environment and releases a very large amount of energy. Whether formed by an asteroid or comet, the kinetic energy of the bolide is transformed at the impact site into high-pressure shock waves that propagate through the target rocks with a velocity much greater than that of sound (Grieve, 1987; Melosh, 1989). Although many details of such energy transfer processes are still not well understood, a clear observation in experimental studies and geological records suggests that the impactor and target rocks are pulverized and ejected into a fireball cloud containing a mixture of vapor, melt products, shocked and unshocked rocks debris, and breccias (Osinski \& Pierazzo, 2012). When the crater formation process ends, only a small portion of the ejected material is deposited directly within the crater once the large majority has been thrown outwards from the impact site. According to Collins et al. (2012), there are four main settings where impact melt-bearing impactites can occur: 1) in large-scale continuous sections within the crater and rim region, which form impact melt sheets and/or smaller isolated bodies; 2) inside or outside of the crater as small glassy particles in impact breccias or in isolation; 3) in the crater floor and walls constituting dike-like bodies of variable size; and 4) discrete glassy particles (spherules or tektites) of wide distribution.

A comparative study on three impact structures of similar size indicates that target lithology plays an important role with respect to the chemical and physical proprieties of products generated by impact melting and, as a result, impactites of sedimentary and crystalline targets differ substantially from one another (Osinski et al., 2008). Depending on the complexity of the geological setting, nature of the target lithology (e.g., sedimentary or crystalline rocks), type of impact structure developed (e.g., simple, complex, multi-ring), age and degree of preservation, it is possible to recognize a wide variety of shock-metamorphosed features in rocks and minerals. Some impact-produced materials include megablock deposits, lithic breccias, lithic breccias with melt particles 
(suevite), melt rock, lithic breccia dikes, intrusive melt dikes, and monomictly brecciated basement (French, 1998). In such lithologies, it is common to observe a mesostasis constituted by the material that was molten and mixed with lithic clasts of the target rock (Grieve et al., 1977; Grieve \& Therriault, 2012). In some cases, impact melt rocks may display a very close similarity in texture and mineralogical assembly to typical igneous rocks. However, it is important to note that adiabatic decompression melting (i.e., magma generating process) is different to impact melting where melting of the target lithology occurs under different degrees of shock metamorphism, causing phase changes and variable degrees of mechanical mixing of the original target rock (Grieve \& Therriault, 2004; Osinski et al., 2012). An important aspect of impact lithologies is that they may contain a series of distinctive microscopic deformation features (i.e., impact indicators) from simple fracturing to complete melting, such as planar deformation features in quartz, mechanical twins in pyroxene, kink-band deformation in mica, granular texture in zircon, diapletic glass, and ballen silica (French, 1998; French \& Koeberl, 2010; Ferrière \& Osinski, 2012). Consequently, impact melt-bearing impactites provide valuable information to better understand how the complex impact crater formation process operates.

We have conducted a comprehensive petrographic examination of a wide range of melt-bearing impactites from an allochthonous breccia deposit within the Colônia impact crater (Brazil). This study is not a review on the subject matter, but represents an important contribution for many other future studies of similar cases. The stratigraphic position of this deposit, between the underlying crystalline basement and overlying crater fill sediments, provides an exceptional opportunity to investigate in detail the processes that govern impact melt generation, as well as the distribution of impact melt rocks and impact glasses, particularly in small structures (diameter less than $4 \mathrm{~km}$ ) developed on crystalline basement targets that have been subjected to intense weathering and erosion.

\section{Geological Setting}

The Colônia impact crater is located about $40 \mathrm{~km}$ southeast of the São Paulo city center in the Parelheiros district (Figure 1b). With a rim-to-rim diameter of about $3.6 \mathrm{~km}$, the structure formed on a crystalline basement complex known as the Ribeira Fold Belt (Hasui et al., 1975). A concentric outer ridge is well visible in a digital terrain elevation model map (Figure 1c). The crater rim rises about $120 \mathrm{~m}$ with respect to the central lowland and is almost completely filled by younger siliciclastic sediments.
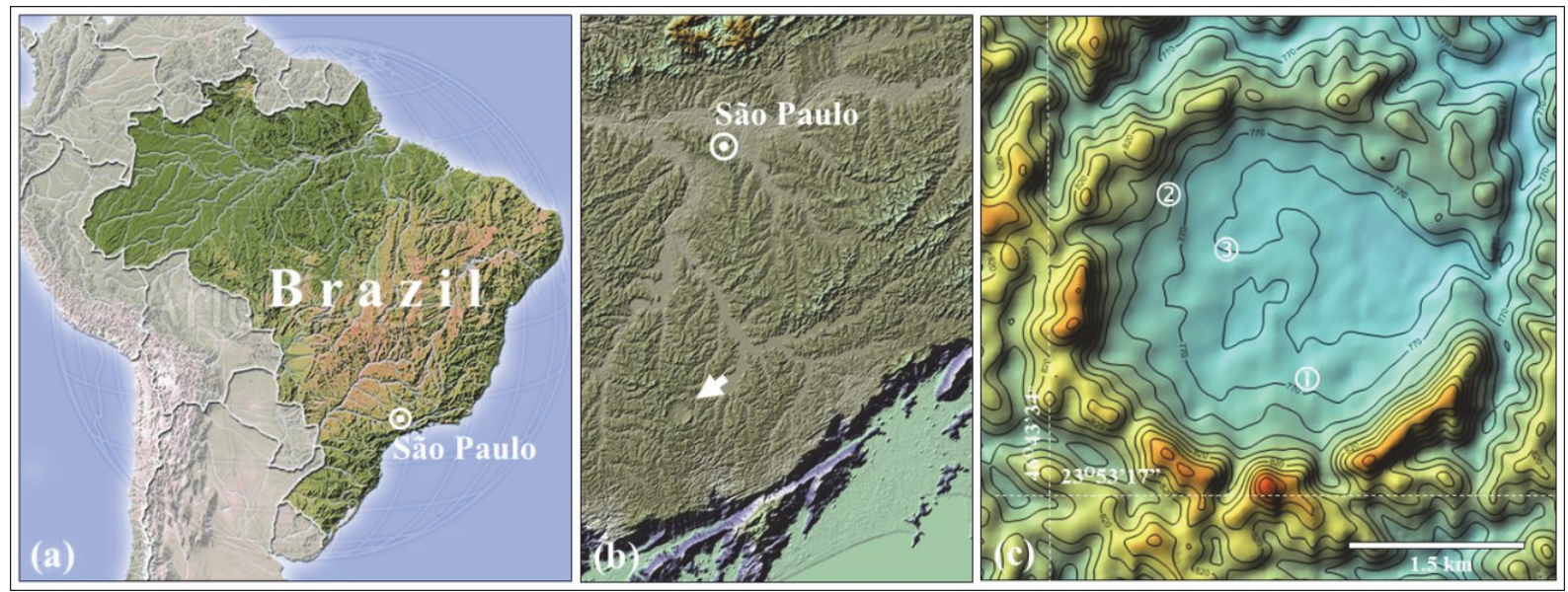

Figure 1. (a) Geographical location of São Paulo city in Brazil; (b) Colônia impact crater (white arrow) in the far south of the São Paulo metropolitan region; (c) Circular geomorphological aspect and borehole sites within the structure: 1, 270 m (Riccomini et al., 2011); 2, 197 m, (Velázquez et al., 2013); 3, 304 m (this study)

The regional geology around the Colônia impact crater can be grouped into three major lithostratigraphic units (Figure 2): 1) Precambrian crystalline basement; 2) Tertiary sediments; and 3) Quaternary deposits. The basement rocks form part of the Embu Complex, which is largely composed of mica schist, granitic gneiss, quartzite, migmatite, diorite, and quartz diorite (Coutinho, 1972; 1980). These lithologies outcrop discontinuously on the outside edge of the crater and are, in general, fairly weathered. Siliciclastic sediments of the Resende Formation of Paleogene age (Riccomini et al., 2011) occur in the form of narrow strip with some hundred metres in length on the south edge of the crater. The youngest sediments are those of Quaternary age, which extend up to the present. This unit is widely distributed within the crater and consists of a succession of alternate layers that comprise chiefly psammitic and organo-pelitic sediments. The most detailed geological 
survey of the crater area was reported by Coutinho $(1972 ; 1980)$, and is the basis for the schematic geological map of Riccomini et al. (2011).

Information about the subsurface units of the Colônia impact crater remain fairly limited. The first geophysical studies of the area were carried out by Motta and Flexor (1991) and Masero and Fontes (1992), who provided a general model for the structure. From the results of one-dimensional direct modelling and interpretation of seismic records, Neves (1998) inferred a maximum depth of $450 \mathrm{~m}$ for the sedimentary fill. A study performed by Riccomini et al. (2011), which integrated new seismic data with the previously published geological data, suggested a thickness of $275 \mathrm{~m}$ with two different intermediate zones. According to Velázquez et al. (2013; 2014), based on a large number of samples obtained in two boreholes that were drilled inside the crater for groundwater exploitation, four different lithological associations may be recognized in these deposits: 1) unshocked crystalline basement rocks formed mostly of mica schist, granitic gneiss, quartzite, and granite; 2) fractured/brecciated basement rocks that show extensive deformation features, such that the brittle and ductile structures are considerably more intense and pervasive than those exposed along the outer crater margin; 3) allochthonous crater-fill deposits, including a complex mixture of lithic fragments, mineral clasts, and molten rocks that were derived from crystalline basement rocks and, more rarely, from older sedimentary rocks; and 4) post-impact deposits that consist of very poorly sorted fine- to coarse-grained siliciclastic sediments, including some intercalations of organo-pelitic materials. In order of abundance, the terrigenous sediments include disaggregated quartz clasts, K-feldspar, mica, tourmaline, and clay minerals. Other smaller constituents are zircon, epidote, biotite, corundum, plagioclase, apatite, anatase, and rutile, as well as lithic fragments of igneous and metamorphic rocks.

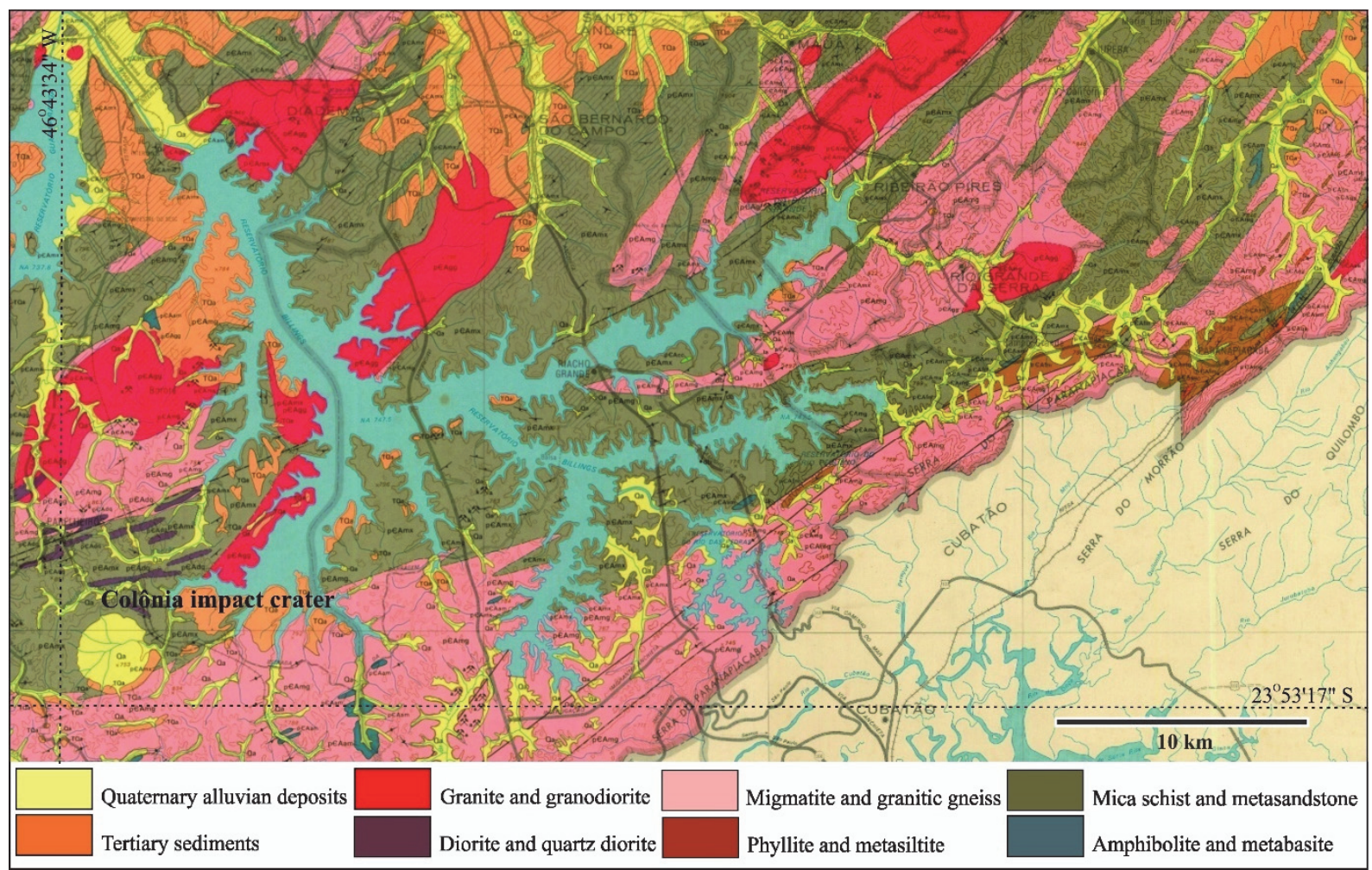

Figure 2. Principal lithological units that outcrop in the Colônia impact crater region (Coutinho, 1980)

\section{Materials and Methods}

The Basic Sanitation Company of São Paulo State (SABESP) recently drill a well to supply drinking water to the local community. This is the first hole with a depth of $304 \mathrm{~m}$, closer to the central part of the crater (Figure 1c). In order to investigate impactite deposits that fill the structure, a total of 152 samples were recovered from this drilling. Fifty samples were selected for standard thin sections and geochemical analysis (major, trace, REE compositions of both whole rock and individual mineral phases). The results of which will be reported in separate manuscript. In this study, we focus on petrographic features of the melt-bearing impactites, chiefly a detailed description of their mineralogy and textural relationships. Observation, identification, description, and 
characterization were performed using an Olympus BX51 microscope with transmitted plane- and cross-polarized light on polished thin sections prepared by Actlabs Laboratories Ltd. (Ancaster, Canada), following the quality control routine of that laboratory.

\section{Petrographic and Mineralogical Characteristics}

The lithologies affected by impact metamorphism at Colônia present a wide variety of different mineralogic compositions, textures, and clast contents. Four main types of impact melt products were recognized: 1) impact melt-bearing breccias; 2) impact melt rocks; 3) selective melting in single mineral grains; and 4) individual discrete bodies. We discuss the petrographic features and mineralogy of each type in the following sections.

\subsection{Impact Melt-Bearing Breccias}

The impact melt-bearing breccias are discrete fragments that were directly generated from the crystalline basement rocks. On a microscopic scale, the breccias commonly contain target rock fragments and mineral clasts, with sharp angular edges in various stages of assimilation, and are very poorly sorted (Figure 3). Target rock fragments include several types of lithic clasts, but crystalline basement clasts, consisting of mica schist, quartzite, granite, and granitic gneiss, are more abundant. Mineral clasts are largely represented by quartz, K-feldspar, plagioclase, and mica. Accessory minerals, such as tourmaline, apatite, zircon, and epidote, occur as individual grains or form the mineral assemblage of lithic clasts. The heterogeneous mesostasis has a reddish-yellow color and reveals a fine mixture consisting mainly of Fe-oxide/hydroxide scattered finely in silicate (melt) glass, tiny quartz grains, microlites of K-feldspar, and phyllosilicate. Millimetric spherules show rounded to oval shapes and are relatively frequent. The contours are defined by tiny grains of opaque minerals and are internally filled with glass that resembles the shape of small droplets (Figures 3b, 3c). Post-depositional incipient alteration is common and results in a partial substitution of the spherules by secondary minerals (goethite + quartz + chlorite). In some samples, the mesostasis is essentially composed of Fe-oxide/hydroxide immersed in a fine-grained partially devitrified mesostasis (Figures 3e, 3f). Different refractive indices and fluidal texture are common features in the mesostasis.
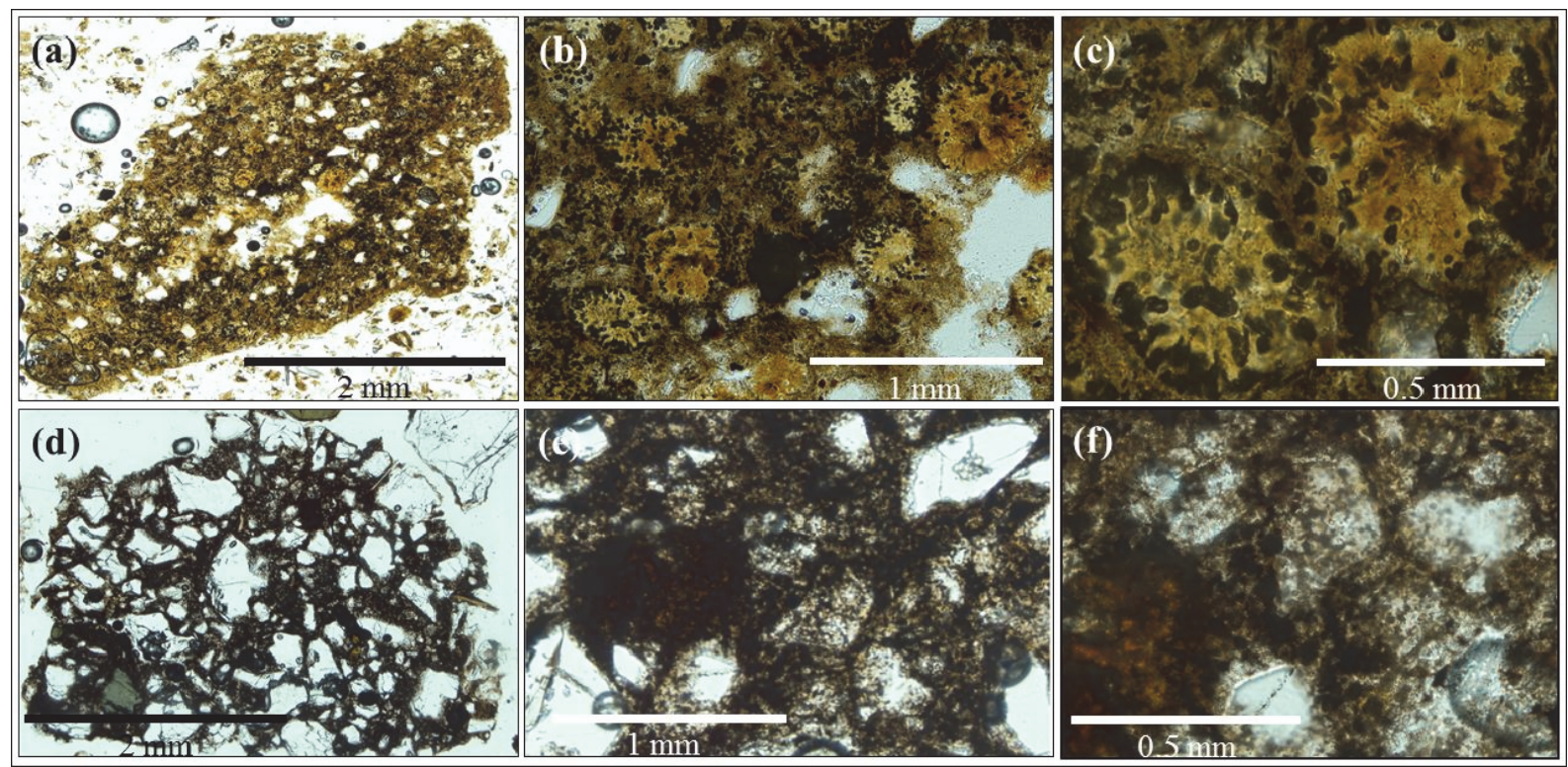

Figure 3. Photomicrography of impact melt-bearing breccias: (a) impact breccia formed by angular mineral clasts of quartz and K-feldspar immersed in a fine mixture consisting mainly of Fe-oxide/hydroxide scattered finely in silicate (melt) glass; (b) and (c) close view of the mesostasis composed mainly of microspherules filled with glass droplets; (d) impact breccia with a prevalence of angular quartz clasts and glass ferruginous mesostasis; (e) and (f) show details of the mesostasis. Note that in (f), the mesostasis is partially recrystallized with polygonal grains boundaries. All images were taken under plane-polarized light

\subsection{Impact Melt Rocks}

Impact melt products contain a wide variety of molten rocks that recrystallized under high pressure and temperature conditions. They are mainly derived from the igneous and metamorphic rocks of the crystalline 
basement. Impact melt lithologies display a highly inequigranular texture, and the geometric arrangements of the mineral grains are often irregular, undulated, and sometimes diffuse. Most of the mineralogical assemblages reveal some kind of transformation in the microstructure, such as a reaction border, crystal intergrowth, or internal texture (Figure 4). Although all of these targets lithologies show an intense effect of shock metamorphism, their primary framework is still visible. Based on the partially preserved primary structure, it is possible to recognize four distinct lithological types from which the impact melt products were generated: 1) granite to granodiorite; 2) granitic gneiss; 3) mica schist; and 4) quartzite.

Impact melt rocks that formed from granite have a very different appearance compared with its parental lithology, although in many respects still resembles the original mineral assemblage (Figures $4 a, 4 b$ ). For example, quartz crystals that are normally uniform and coarse-grained in acidic plutonic rocks appear with notable grain size reduction, forming glomerogranular quartz aggregates, and are notoriously susceptible to the development of undulose or mosaic extinction. The K-feldspar and plagioclase grains are, on average, greater than $1 \mathrm{~mm}$ with crystal faces entirely absent and rounded edges; they present fine deformation features, undulose extinction, and several mineral grain inclusions. A wide range of intergrowth textures with complex patterns is observed between single elongated grains of K-feldspar and quartz. Characteristic vermicular shapes of the grains are only a few of the habits that the quartz commonly exhibits within K-feldspar. Other unusual shapes, including oblongs, droplets, and rods, may be present. In many cases, the absence of replacement reactions is observed within partially preserved parent grains of a wide variety of shapes. The random arrangement of quartz grains within $\mathrm{K}$-feldspar strongly indicates that the intergrowth process must have occurred during rapid solidification of the host crystal. Biotite lamellae, ranging between $0.3 \mathrm{~mm}$ and $1.5 \mathrm{~mm}$, also present evidence of deformation. Although it shows the same parallel extinction under cross-polarized light, an aureole of a reabsorption edge is often also observed. This partial melting is characterized by the precipitation of fine opaque mineral grains along the edge, forming continuous parallel layers around the skeletal biotite, which displays textures consistent with crystal-bonded aggregates.

One of the most remarkable consequences of the impact cratering process on the target rock is the breakdown of the original framework and modification to a seemingly isotropic igneous structure. In such cases, the most affected metamorphic rocks display nearly a complete absence of planar foliation. A careful petrographic observation may therefore be required to identify the transformation features correctly. The granitic gneiss samples with shock effects from the Colônia structure look like felsic plutonic igneous rocks with a granular phaneritic and sometimes porphyritic texture (Figures 4c, 4d). Xenomorphic grains of feldspar (both orthoclase and microcline), plagioclase, quartz, and biotite are the most frequent. The relative abundance of each mineral can vary considerably, and the grain sizes are generally between $0.3 \mathrm{~mm}$ and $0.7 \mathrm{~mm}$, but feldspar-rich samples may contain crystals up to $2 \mathrm{~mm}$. It is common to observe K-feldspar crystals with rounded edges, showing fine multiple cross-hatched twinning that was partially preserved. An important aspect of such grains is the intense deformation of twinning lamellae that often appear bent, folded, twisted, and even broken. The most typical transformation characteristic in plagioclase grains is the occurrence of abundant inclusions of small quartz grains with rounded edges. The general visual aspect can be compared to that of the poikiloblastic texture. However, the several discrete quartz grains are often aligned along the plagioclase polysynthetic twinning. The contact relationship is highly sinuous and the extinction position is markedly different between the quartz grains and host crystal. Many plagioclase grains display indicators of recrystallization that often form aggregates in narrow elongate zones. Deformation of the polysynthetic twinning is also common. Biotite shreds, mostly $>0.5 \mathrm{~mm}$, occur as anhedral unoriented grains with very irregular edges, intense strain shadows, and kinks. Extensive recrystallization of the biotite is evidenced by the absence of cleavage, highly irregular edges, and undulatory extinction, which appears unevenly across the crystal. The majority of quartz grains have rounded edges and usually form aggregates with globular, reniform, and oval shapes. Minor segregations of amoeboid-shaped quartz also sometimes occur between K-feldspar grains, revealing sutured boundaries and undulose extinction.

Schistose rocks that outcrop in the region surrounding the Colônia impact crater do not show evidence of shock metamorphism. These rocks are essentially constituted of medium- to coarse-grained mica (muscovite, biotite) interleaved with fine to medium quartz grains. The schists (mica schist and/or quartz schist) contain enough platy metamorphic minerals in alignment to exhibit a marked foliation. However, under extreme shock metamorphism, the primary schistosity was completely transformed and the regular shape of the mineralogical components was deeply altered. The plates of mica and quartz grains were considerably reduced in size - so much that the mineral arrangement now resembles an igneous quench texture. In this isotropic fabric, molten biotite flakes partly appear to form submicroscopic grains, while another phase crystallizes into a lath shape with an aspect of swallowtail (sillimanite?), and quartz grains present visibly globular shape boundaries (Figure 4e). 
In the vast majority of cases, the quartzite is a monomineralic rock consisting largely of medium to coarse quartz grains. However, some samples may exhibit discrete mineralogical variations and other constituents, such as tourmaline, zircon, and epidote, may be present. The texture is typically granoblastic polygonal, without preferential orientation of the mineralogical components, in which triple-point intersections are commonly made at $120^{\circ}$ angles, and the grains are mostly monocrystalline quartz. The foremost distinction between pre- and post-impact quartzite is the typical annealed texture superimposed on a dynamo-metamorphic heterogranular polygonal texture. As a result, the new rock fabric is formed by quartz grains that show edges with significant negative curvature and, instead of a polygonal intersection at $120^{\circ}$, the pressure dissolution and grain boundary migration increase, leaving visible records of successive deformation phases (Figure 4f). Undulose extinction may be observed in some grains that form a mosaic pattern.
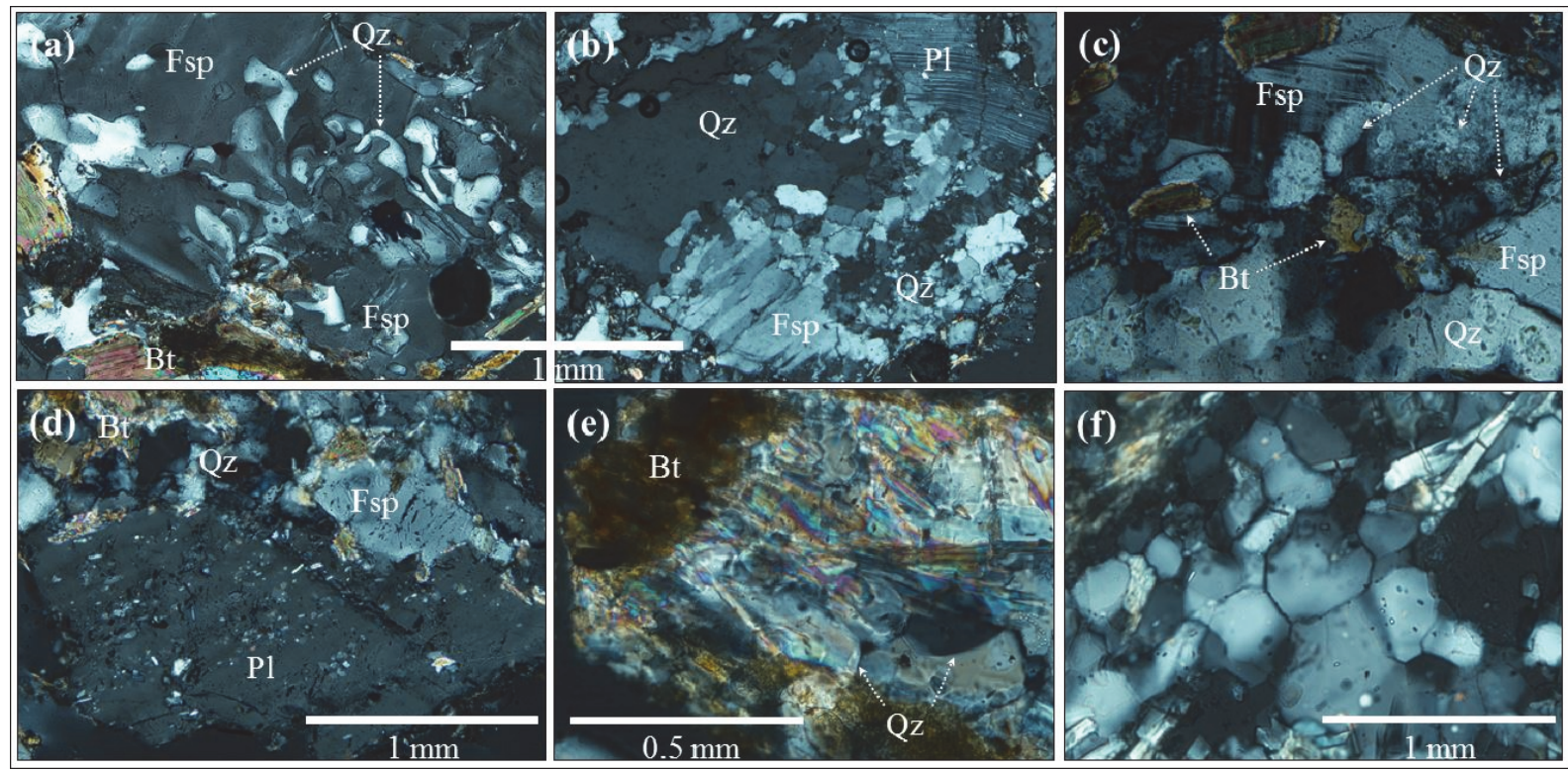

Figure 4. Photomicrography of impact melt rocks: (a) and (b) show melt rock generated from the granite target; (a), the K-feldspar (Fsp) is characterized by a poikiloblastic appearance with inclusions of quartz grains (Qz) taking various sizes and shapes; (b) a similar sample displays an allotriomorphic texture with K-feldspar (Fsp) and plagioclase $(\mathrm{Pl})$ grains presenting intense lamellar deformation. Qz appear to form polycrystalline aggregates or interstitial-xenomorphic quartz; (c) and (d) show melt rock produced from the granitic gneiss target exhibiting granular allotriomorphic texture. Note that in (c), the interlocking between the Qz and Fsp are usually globular,

reniform, and oval shapes, and the biotite (Bt) grains have irregular shapes. In contrast, (d) illustrates a recrystallized Pl grain with several small inclusions of quartz grains along the twinning plane; (e) melt rock originating from the biotite schist target shows an isotropic fabric composed of molten biotite flakes, Qz with noticeable globular shape boundaries, and another phase crystallizes in swallow-shaped slats (sillimanite?); (e) melt rock made from the quartzite target reveals a polygonal texture with a dihedral angle between grains. All images were taken under cross-polarized light

\subsection{Selective Melting in Single Mineral Grains}

The whole or partial melting of a pre-existing mineral grain is a very important feature of impact melt products. The reactions involved in this process are complex and the mechanisms of new microstructure formation can occur, at the very least, in three different possible situations: 1) direct crystallization from mineral melt; 2) spinodal decomposition texture; and 3) heterogeneous mixture of molten minerals.

Crystallization of a new phase from a melt is most frequently observed. In general, the melting-growth process is observed in biotite and K-feldspar grains. In the case of biotite grains, the process results in the generation of very fine crystals of phyllosilicates and irregular aggregates of opaque minerals in a silica cryptocrystalline hot mesostasis (Figure 5a). The presence of metallic oxide precipitation and yellow brown amorphous material in close association with the remaining biotite grains are strong evidence that decomposition has occurred. The melting process occurred non-uniformly and most likely without interference from other minerals.

With regards to the K-feldspar grains, the effect of the intense decomposition caused a complex mixture of 
microcrystalline quartz and $\mathrm{K}$-feldspar ribbons (Figures $5 \mathrm{~b}, 5 \mathrm{c}$ ). In this combination, $\mathrm{K}$-feldspar exsolution lamellae, with lenticular shapes of variable width and wedge-shape terminations, are surrounded by a fine aggregate of microcrystalline quartz. The distribution between separate phases is markedly different and partial melting of K-feldspar under high-pressure conditions is the more favorable mechanism to explain the formation of the decompositional melting textures.

The effect of spinodal decomposition has been observed in a smaller number of samples, and is more direct evidence that the silicate minerals underwent melting by an extreme thermal shock generated in an almost perfect hybrid homogeneous phase. The rapidly cooling liquid gives rise to a fingerprint texture (Figures $5 \mathrm{~d}, 5 \mathrm{e}$ ), connected snake-like patterns, with two separate phases: one which essentially consists of pure microcrystalline quartz with undulose extinction; and an unknown phase in which the grains size is below the resolution of the light-optical microscope, making them difficult to identify. A more detailed study is necessary to better define the morphological characteristics, grain sizes, and chemical composition of the two phases. Nevertheless, the close spatial relationship observed between residual quartz grains and muscovite with the fingerprint texture indicates that the textural difference was generated by the melting of those minerals, under thermodynamic conditions where the phases change very quickly from a liquid into solid state. The textural pattern reported here is very similar to results obtained by Gonnella et al. (1997).

The heterogeneous mixture of molten minerals is frequently found involving biotite and quartz grains; in most of which only a small part of the remaining grains of the melted minerals can be identified. In such cases, discrete skeletal grains are immersed in a finely recrystallized mesostasis that displays a distinctive heterogeneous flow structure, which is locally separated by a dark slim strip that contains numerous tiny grains of opaque minerals (Figure 5f). In another similar section, the recrystallized mesostasis is composed of several minuscule convex globules with similar morphology to those of ballen silica. However, these globules are unevenly distributed in the mesostasis and the boundaries reveal a lobate anisotropic swelling and display birefringence with first order values, as well as undulatory extinction. The presence of such microstructures (i.e., residual dark flow lines and relict parental grains) are indicative of a dramatic chemical change of the minerals, involving high strain energy sufficient to break strong bonds and promote the observed recrystallization reactions. A misorientation between grains of the phases present on the microscopic scale suggests that this process took place over a relatively short period of time.
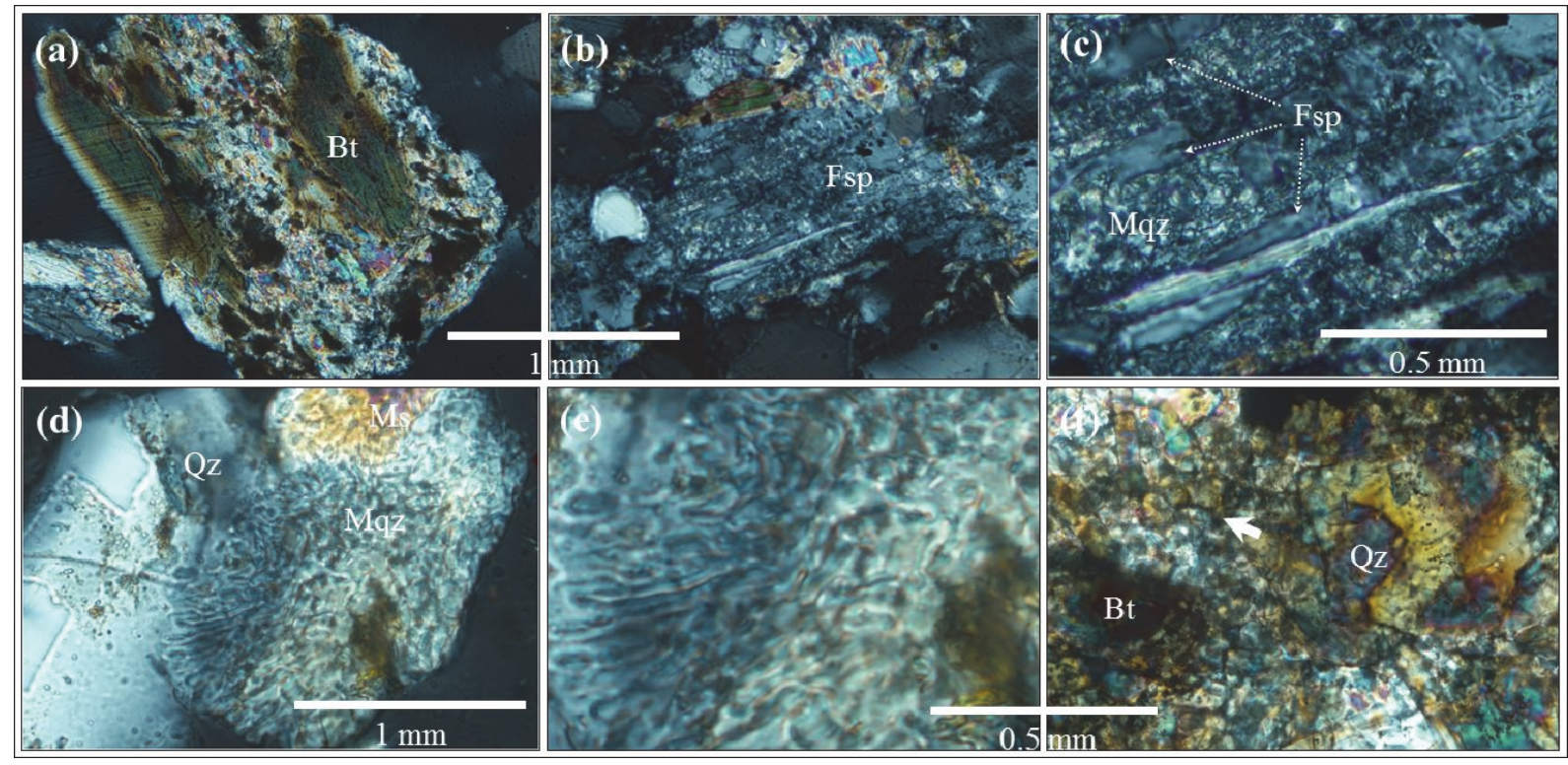

Figure 5. Photomicrography of selective melting in single mineral grains: (a) example of partial melting of biotite generating a new phase (metallic oxide) and new biotite grain; (b) partially melted K-feldspar grain (Fsp) and (c) close view of a complex mixture of microcrystalline quartz (Mqz) and Fsp ribbons; (d) Spinodal decomposition texture from the melting of muscovite (Ms) and quartz (Qz) grains and (e) detail of the texture with a snake-like pattern composed in part by Mqz; (f) heterogeneous mixture involving melting of biotite (Bt) and Qz grains. Note that at the interface between the remaining parental grains, the mesostasis is composed of several minuscule convex anisotropic globules (white arrow). All images were taken under cross-polarized light 


\subsection{Individual Discrete Bodies}

A large number of individual discrete bodies were found in the allochthonous crater-fill deposits (Figure 6). In general, these materials occur within a specific depth range that may vary between $224 \mathrm{~m}$ and $180 \mathrm{~m}$, and is most frequent at $198 \mathrm{~m}$. A simple elutriation technique was employed to remove fine particles $(<0.01 \mathrm{~mm})$. The separation was done from a fraction of $0.35 \mathrm{~mm}$ and $1.5 \mathrm{~mm}$ using a binocular stereomicroscope with $100 \mathrm{x}$ magnification. These small bodies may range in size from tiny particles smaller than $0.25 \mathrm{~mm}$ up to an intermediate size sand grain $(>1.5 \mathrm{~mm})$. They occur as individual grains but accretionary spherules are also common. In this latter case, the contact between the grains indicates that accretion occurred by collision, with the particles still in free-rotation movement and in the silico-plastic state or partially molten (Figure 6a). The shapes and the surface features are the most outstanding characteristics. Some are noticeably splash kinematic shapes with variations for spherule, oval, and droplet, and others display a more irregular shape, having greater similarity with a sub-angular melt object (Figures 6b, 6c, 6f). The surface is covered by a succession of sculpted shapes, including microcraters, pits, grooves, and molten surface features. Another important particularity of those small bodies is the presence of vesicles. Despite the fact that not all samples have vesicles, it is possible to note that the cavity of the sub-angular fragment particles is usually different from those particular spherules. Some vesicles are completely or partly filled with very fine-grained minerals. Furthermore, the distinctive shapes of the cavities edges suggest that were formed from gas bubbles. A total of 20 small bodies were chosen for more specific studies, including classical petrographic techniques, scanning electron microscopy, and electron probe microanalysis, in order to characterize the mineralogy, texture, and chemical composition. Preliminary observations using a binocular stereomicroscope under light reflected reveal that spherules and sub-angular fragment particles show a noticeable metallic and vitreous luster.
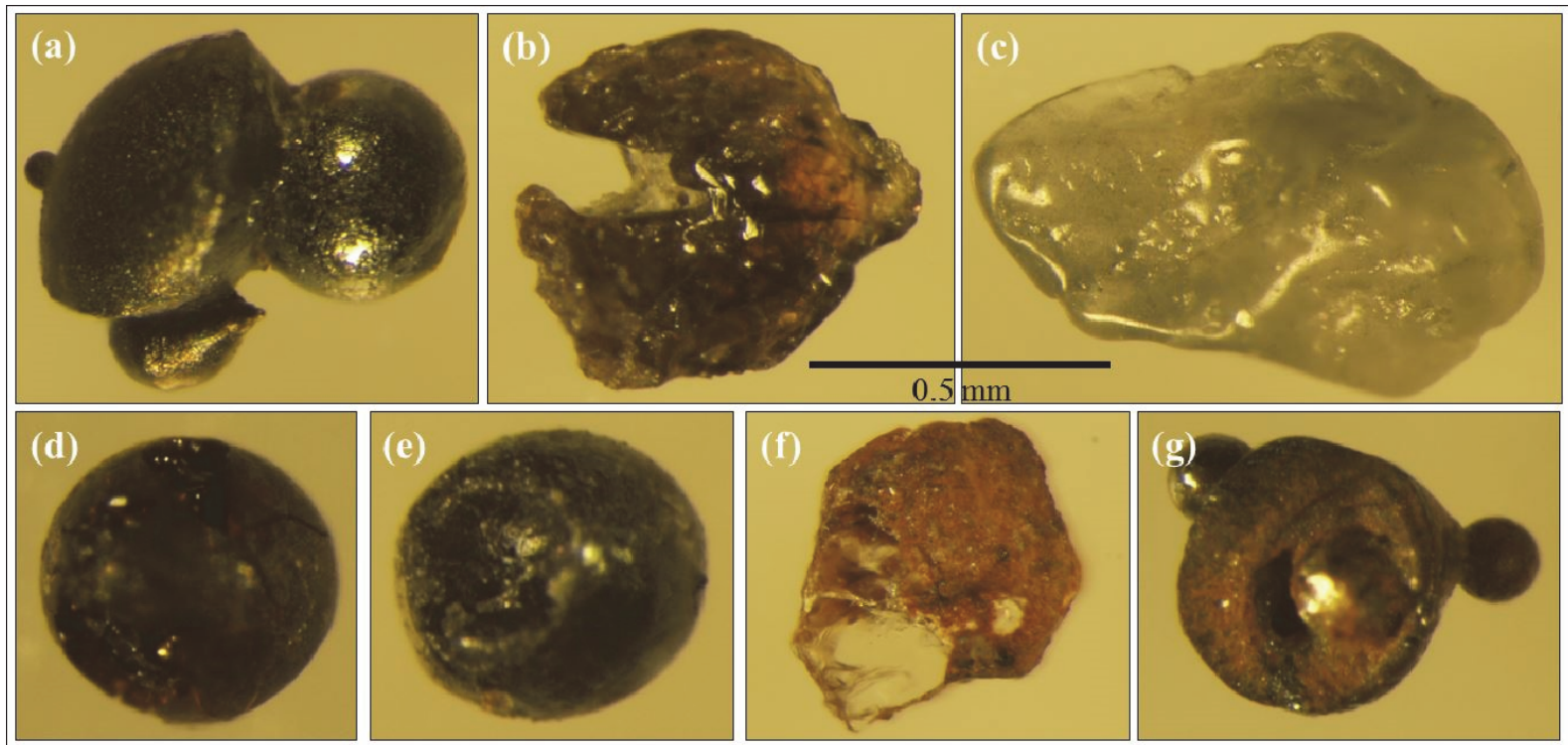

Figure 6. Stereomicroscope digital photography of individual discrete bodies: (a), (d), (e), and (g) show spherules varying from round, oval to droplet; and (b), (c), and (f), subangular fragments showing irregular shapes and fluidal texture on the surface. Note that in (a) and (g), the spherules form several accretionary grains. Small bubbles rounded or elongated cavities are noticeable in (b), (f) and (g)

\section{Final Considerations}

Several theoretical models and geological studies have been conducted to examine the physical and chemical processes involved during the formation of impact craters (Grieve et al., 1977; Melosh, 1989; French, 1998; Dence, 2002; Osinski \& Pierazzo, 2012). Kinetic energy transformed into high-pressure shock waves at the impact may cause an intense transformation in the target rocks, forming a wide variety of unusual microstructures of irreversible changes (Dence et al., 1977; Langenhorst, 2002). Like an ordinary stress wave, the shock wave carries energy and its supersonic propagation through the target material can cause overheating, leading to the formation of a large quantity of melt products (French, 1998; Osinski et al., 2012; Zhang, 2016). Materials formed under such conditions are called impact melt rocks, and can display a completely different textural and mineralogical arrangement from their parental material. 
The Colônia impact crater was formed on Precambrian crystalline basement and the lithological association is largely composed of ancient igneous and metamorphic rocks. A careful petrographic characterization of target rock transformation was conducted on fifty polished thin sections prepared from drilling samples recovered from several crater-fill deposit layers at different depths. One of the main results of the investigation is the discovery of an expressive occurrence of impact melt products that were generated from different types of crystalline rocks.

The effects of high shock pressures caused a large number of irreversible transformations. The textural changes in both igneous and metamorphic rocks are clearly indicative of intense deformation, in which the minerals present undulose extinction and comminution into tiny new grains. In general, plutonic rocks of granitic composition mainly exhibit an interlocking unequigranular texture of feldspar, quartz, and scattered biotite. Large subangular K-feldspar grains usually have an uncommon poikilitic texture, in which quartz grains with different shapes occur as inclusions, suggesting that its development was substantially induced by high-stress plastic deformation. A few initially large grains or more resistant minerals may remain in the mesostasis with the appearance of crushed material. This is the case of some quartz crystals, where the grains have been strongly cataclasized and recrystallized, forming polycrystalline aggregates with undulose extinction and subgrains that show sutured grain boundaries. In some samples, however, quartz may be present in interstitial spaces displaying a marked fluidal texture. The distinguishing feature of the metamorphic rocks under the effects of high shock pressures is essentially a breaking of the primary original fabric. The complete loss of banding and schistosity registered in granitic gneiss and mica schist, respectively, is an example of the intense transformation of shapes and arrangement of the mineralogical components. The gneisses have a conspicuous resemblance with plutonic igneous rocks more than to those of the metamorphic group. Feldspar and quartz grains are very irregular in shape with highly lobate and sinuous boundaries. Other useful indicators of texture transformation are small quartz inclusions with rounded edges that occur along the cleavage plane of plagioclase crystals. The inclusions have elongated shapes and are aligned parallel to the albite polysynthetic twinning. Such characteristics are clearly indicative of a dynamic recrystallization driven by strain energy with sufficient force to cause grain migration. Large and strongly deformed plagioclase grains with bent twinning and local kink-like features are also often present. The primary mica schist fabric was markedly transformed. As may be deduced by the optically observed microstructures, incongruent melting of the mineralogical components produced a successive new texture, and the resulting rock displays typically random textural fabrics. Biotite flakes were partially replaced by an isotropic material associated with metallic oxides, and quartz grains display a typically globular shape in the absence of sharp boundaries.

With regards to the pre-impact quartzite, the following textural features were recognized: non-foliation, mostly equigranular, granoblastic, and regular polygonal boundaries between grains. The main effect of the shock pressures is the textural transformation, reorganization of sizes, shapes and grain boundaries by dynamic recrystallization. Despite the essentially polygonal appearance of boundaries, the internal angles between grains are notably different and most quartz grains present optical evidence of considerable intracrystalline deformation. This fact is due to a rearrangement of the texture with new grains that grew from parental grains that were already initially deformed. Likewise, the melt may have occurred as an intergranular fluid and precipitated afterwards along low differential stress voids and grain boundaries.

Several researchers have argued that shock melting of individual silicate minerals occurs at much higher temperatures than any other endogenous geological process, and the mechanism is given according to the specific physical conditions of each mineral grain (French, 1998; Osinski \& Pierazzo, 2012; Keulen et al., 2015). Despite the fact that the melting process may have occurred within a single setting, careful microscopic examination on individual grains of biotite, $\mathrm{K}$-feldspar, and quartz reveals that the microstructures present in those minerals formed under different physical conditions. Changes in small-scale textures caused by the partial melting are clearly noticeable on the biotite parental grains, among which are highlighted the precipitation of $\mathrm{Fe}$ oxide minerals (magnetite), formation of an amorphous phase, and crystallization of new grains. The most frequent melting feature in K-feldspar grains is the occurrence of discrete lenses with highly irregular edges confined in a mesostasis of fine-grained polycrystalline quartz, indicating that both phases crystallized very rapidly from a common liquid. A similar interpretation was postulated by Keulen et al. (2015) to explain the origin of some microstructures in K-feldspar from granitic rocks of the Maniitsoq structure, Greenland.

With respect to the quartz grains, two different situations were present. First, sudden cooling and small oscillations in composition and density from the melting of the quartz + muscovite couple gave rise to the formation of a spinodal decomposition texture. This separation mechanism is characteristic of the very rapid cooling of a viscous fluid in which different phases coexist, which is well documented in several silicate 
minerals (Christie, 1968; Ghose et al., 1972; Takeda et al., 1989; Menna et al., 2008; Sánchez-Muñoz et al., 2016). Second, the melting of the quartz + biotite couple generated a complex mixture with a clear fluidal texture of fine aggregates of opaque minerals, globular-looking microcrystalline quartz, and small new grains of biotite. Similar features have been widely described by Schmieder et al. (2008) from the Paasselkä impact structure, SE Finland, located within the crystalline basement.

The occurrence of a large number of individual discrete bodies with shapes of spherules or fragments, inside or outside of a crater, resulting from impact melting is well known in the literature (Suess, 1990; Melosh \& Vickery, 1991; Schulte et al., 2003; Misra et al., 2009; Cukierski, 2013). The small bodies described in the previous section were found at depths varying between $224 \mathrm{~m}$ and $180 \mathrm{~m}$ within the crater. As for the shape, two types prevailed: spherules that are generally in round, oval and droplet shapes; and sub-angular fragments, which have a less regular external appearance than the former, and present a fluid surface texture as its main morphological feature. The presence of features indicative of high-energy collisions, surfaces with microcraters, spherules with welded grains, as well as small bubbles with rounded or elongated cavities in both materials, is consistent with generation from a viscous fluid by ballistic origin. Based on these characteristics, which are similar to several other spherules and glass fragments of ballistic origin (e.g., Hörz et al., 2002; Schulte et al., 2003; Wu et al., 2013, Belsa et al., 2017), an impact origin seems to be the most consistent interpretation. However, more detailed studies are being conducted in order to gather other information that may potentially represent irreversible fingerprints about important geological processes that took place in the past.

Although this investigation mainly focused on the petrographic characterization of effects produced by shock-wave propagation through target rocks, a number of important considerations can be delineated from the results presented above. The wide diversity of the impact melt products and textural transformations reported at Colônia impact crater resulted from different stress rates activated by the high shock pressures on a heterogeneous target lithology. The occurrence of individual bodies, spherules, sub-angular fragments, selective mineral melting, and spinodal decomposition textures are transformations that involve an irreversible significant change of shape, which characterize a thermodynamic environment of very high pressure and temperature conditions. Such microstructures provide valuable information on the deformation mechanisms and microscale physical and chemical processes that influence the structural and textural rearrangement of crystalline basement target rocks. The petrographic data indicate that such factors differ in detail for each shock metamorphic feature.

\section{Acknowledgments}

We received aid from a large number of people during the preparation of this paper. We are grateful to the colleagues of the EACH-USP and IG-SMA for their help and support. We extend special thanks to Prof. Dr. Fernando Carbayo Baz for his generous assistance in the acquisition of images. W. Sallun Filho is researcher with a Productivity Grant of CNPq, Brazil. We are grateful to the anonymous referees who substantially improved the quality of this manuscript. This study has been supported by the FAPESP foundation, Proc. No. 2011/50987-0 and 2012/50042-9.

\section{References}

Belsa, J., Goderis, S., Montanari, A., Vanhaecke, F., \& Caleys, P. (2017). Petrography and geochemistry of distal spherules from the K-Pg boundary in the Umbria-Marche region (Italy) and their origin as fractional condensates and melts in the Chicxulub. Geochimica et Cosmochimica Acta, 202, 231-263. https://doi.org/10.1016/j.gca.2016.12.018

Christie, O. H. J. (1968). Spinodal precipitation in silicates. I. Introductory application to exsolution in feldspar. Lithos, 1(2), 187-192. https://doi.org/10.1016/S0024-4937(68)80009-X

Collins, G. S., Melosh, H. J., \& Osinski, G. R. (2012). The Impact-Cratering Process. Elements, 8(1), 25-30. https://doi.org/10.2113/gselements.8.1.25

Coutinho, J. M. V. (1972). Petrologia do pré-Cambriano em São Paulo e arredores. Boletim IG, 3, 5-99.

Coutinho, J. M. V. (1980). Carta geológica da região metropolitana da Grande São Paulo, 1:100.000. São Paulo, SP: EMBLASA.

Cukierski, D. O. (2013). Textural and compositional analysis of Fe-Ni metallic spherules in impact melt from Monturaqui Crater, Chile (Unpublished master's thesis). University of Iowa.

Dence, M. R. (2002). Re-examining Structural Data from Impact Craters on the Canadian Shield in the Light of Theoretical Models. In Impacts in Precambrian shields (pp. 59-79). Springer. https://doi.org/10.1007/978-3-662-05010-1_2 
Dence, M. R., Grieve, R. A. F., \& Robertson, P. B. (1977). Terrestrial impact structures-Principal characteristics and energy considerations. In Impact and explosion cratering: Planetary and terrestrial implications (pp. 247-275).

Ferrière, L., \& Osinski, G. R. (2012). Shock metamorphism. Impact Cratering: Processes and Products, Chichester, Uk: Wiley Online Library.

French, B. M. (1998). Traces of catastrophe: A handbook of shock-metamorphic effects in terrestrial meteorite impact structures. Technical Report, LPI-Contrib-954.

French, B. M., \& Koeberl, C. (2010). The convincing identification of terrestrial meteorite impact structures: What works, what doesn't, and why. Earth-Science Reviews, 98(1-2), $123-170$. https://doi.org/10.1016/j.earscirev.2009.10.009

Ghose, S., Phakey, P. P., \& Tidy, E. (1972). Spinodal decomposition in an alkali amphibole. Geol. Soc. America Abstracts, 4, 516.

Gonnella, G., Orlandini, E., \& Yeomans, J. M. (1997). Spinodal Decomposition to a Lamellar Phase: Effects of Hydrodynamic Flow. Physical Review Letters, 78(9), 1695-1698. https://doi.org/10.1103/PhysRevLett.78.1695

Grieve, R. A. F. (1987). Terrestrial Impact Structures. Annual Review of Earth and Planetary Sciences, 15(1), 245-270. https://doi.org/10.1146/annurev.ea.15.050187.001333

Grieve, R. A. F., \& Therriault, A. M. (2004). Observations at terrestrial impact structures: Their utility in constraining crater formation. Meteoritics \& Planetary Science, 39(2), $199-216$. https://doi.org/10.1111/j.1945-5100.2004.tb00336.x

Grieve, R. A. F., \& Therriault, A. M. (2012). Impactites: Their Characteristics and Spatial Distribution. In Impact Cratering (pp. 90-105). Chichester, UK: John Wiley \& Sons, Ltd. https://doi.org/10.1002/9781118447307.ch7

Grieve, R. A. F., Dence, M. R., \& Robertson, P. B. (1977). Cratering processes - As interpreted from the occurrence of impact melts. In Impact and explosion cratering: Planetary and terrestrial implications (pp. 791-814).

Hasui, Y., Carneiro, C. dal R., \& Coimbra, A. M. (1975). The Ribeira folded belt. Revista Brasileira de Geociências, 5(4), 257-266.

Hörz, F., Mittlefehldt, D. W., See, T. H., \& Galindo, C. (2002). Petrographic studies of the impact melts from Meteor Crater, Arizona, USA. Meteoritics \& Planetary Science, 37(4), 501-531. https://doi.org/10.1111/j.1945-5100.2002.tb00836.x

Keulen, N., Garde, A. A., \& Jørgart, T. (2015). Shock melting of K-feldspar and interlacing with cataclastically deformed plagioclase in granitic rocks at Toqqusap Nunaa, southern West Greenland: Implications for the genesis of the Maniitsoq structure. Tectonophysics, 662, 328-344. https://doi.org/10.1016/j.tecto.2015.07.028

Langenhorst, F. (2002). Shock metamorphism of some minerals: Basic introduction and microstructural observations. Bulletin of the Czech Geological Survey, 77(4), 265-282. Retrieved from http://www.geology.cz/bulletin/fulltext/03langenhorstfinal.pdf

Masero, W. C. B., \& Fontes, S. L. (1992). Geoelectrical studies of the Colônia impact structure, Santo Amaro, State of Sao Paulo - Brazil. Revista Brasileira de Geofisica, 10(5), 25-41.

Melosh, H. J. (1989). Impact cratering: A geologic process. Research Supported by NASA. New York, Oxford University Press (Oxford Monographs on Geology and Geophysics, No. 11), 1989, 253 P., 11.

Melosh, H. J., \& Vickery, A. M. (1991). Melt droplet formation in energetic impact events. Nature, 350(6318), 494-497. https://doi.org/10.1038/350494a0

Menna, M., Tribaudino, M., \& Renzulli, A. (2008). Al-Si order and spinodal decomposition texture of a sanidine from igneous clasts of Stromboli (southern Italy): insights into the timing between the emplacement of a shallow basic sheet intrusion and the eruption of related ejecta. European Journal of Mineralogy, 20(2), 183-190. https://doi.org/10.1127/0935-1221/2008/0020-1795

Misra, S., Newsom, H. E., Prassad, M. S., Geissman, J. W., Dube, A., \& Sengupta, D. (2009). Geochemical identification of impactor for Lonar crater, India. Meteoritics \& Planetary Science, 44(7), 1001-1018. 
https://doi.org/10.1111/j.1945-5100.2009.tb00784.x

Motta, U. S., \& Flexor, J. M. (1991). Estudo Gravimétrico da Depressão Circular de Colônia, São Paulo, Brasil. In 2nd International Congress of the Brazilian Geophysical Society.

Neves, F. A. (1998). Estudo da depressão circular de Colônia-SP pelo método sísmico. Revista Brasileira de Geociências, 28(1), 3-10.

Osinski, G. R., \& Pierazzo, E. (Eds.). (2012). Impact Cratering: processes and products. Chichester, UK: John Wiley \& Sons, Ltd. https://doi.org/10.1002/9781118447307

Osinski, G. R., Grieve, R. A. F., Cllins, G. C., Marion, C., \& Silvester, P. (2008). The effect of target lithology on the products of impact melting. Meteoritics \& Planetary Science, 43, 1939-1954. https://doi.org/10.1111/j.1945-5100.2008.tb00654.x

Osinski, G. R., Grieve, R. A. F., Marion, C., \& Chanou, A. (2012). Impact Melting. In Impact Cratering (pp. 125-145). Chichester, UK: John Wiley \& Sons, Ltd. https://doi.org/10.1002/9781118447307.ch9

Riccomini, C., Crósta, A. P., Prado, R. L., Ledru, M. P., Turcq, B. J., Santa'anna, L. G., ... Reimold, W. U. (2011). The Colônia structure, São Paulo, Brazil. Meteoritics \& Planetary Science, 46(11), 1630-1639. https://doi.org/10.1111/j.1945-5100.2011.01252.x

Sánchez-Muñoz, L., del Campo, A., \& Fernández, J. F. (2016). Symmetry constraints during the development of anisotropic spinodal patterns. Scientific Reports, 6(1), 20806. https://doi.org/10.1038/srep20806

Schmieder, M., Moilanen, J., \& Buchner, E. (2008). Impact melt rocks from the Paasselkä impact structure (SE Finland): Petrography and geochemistry. Meteoritics \& Planetary Science, 43(7), 1189-1200.

Schulte, P., Stinnesbeck, W., Stüben, D., Kramar, U., Berner, Z., Keller, G., \& Adatte, T. (2003). Fe-rich and K-rich mafic spherules from slumped and channelized Chicxulub ejecta deposits in the northern La Sierrita area, NE Mexico. International Journal of Earth Sciences, 92(1), 114-142. https://doi.org/10.1007/s00531-002-0304-9

Suess, F. E. (1900). Die Herkunft der Moldavite und verwandter Gläser. Geologischen Reichsanstalt, 50, 193-382.

Takeda, H., Mori, H., \& Ogata, H. (1989). Mineralogy of augite-bearing ureilites and the origin of their chemical trends. Meteoritics, 24(2), 73-81. https://doi.org/10.1111/j.1945-5100.1989.tb00947.x

Velázquez, V. F., Colonna, J., Sallun, A. E. M., Azevedo Sobrinho, J. M., Sallun Filho, W., \& Paiva, P. C. A. (2014). The Colônia Impact Crater: Geological Heritage and Natural Patrimony in the Southern Metropolitan Region of São Paulo, Brazil. Geoheritage, 6(4), 283-290. https://doi.org/10.1007/s12371-014-0121-0

Velázquez, V. F., Riccomini, C., Sobrinho, J. M. A., Pletsch, M. A. J. S., Sallun, A. E. M., Filho, W. S., \& Hachiro, J. (2013). Evidence of Shock Metamorphism Effects in Allochthonous Breccia Deposits from the Col\&amp;\#244;nia Crater, S\&amp;\#227;o Paulo, Brazil. International Journal of Geosciences, 4(1), 274282. https://doi.org/10.4236/ijg.2013.41A025

Wu, Y., Sharma, M., LeCompte, M. A., Demitroff, M. N., \& Landis, J. D. (2013). Origin and provenance of spherules and magnetic grains at the Younger Dryas boundary. Proceedings of the National Academy of Sciences, 110(38), E3557-E3566.

Zhang, Z. X. (2016). Rock fracture and blasting: theory and applications. Butterworth-Heinemann.

\section{Copyrights}

Copyright for this article is retained by the author(s), with first publication rights granted to the journal.

This is an open-access article distributed under the terms and conditions of the Creative Commons Attribution license (http://creativecommons.org/licenses/by/4.0/). 